ISBN 978-81-933894-1-6

2017 International Conference on Studies in Business Management, Law and Education

(SBMLE-17)

Kyoto (Japan) April 20-21, 2017

\title{
Critical Analyses of Leadership Style in One of Indonesian Primary School
}

\author{
Agung Prasetyo Wibowo
}

\begin{abstract}
Previous research has shown that Indonesia is currently experiencing a crisis in school leadership. In key studies of school principals' role in upgrading school components and making improvement, the role was identified as autocratic where the good practices such as shared-decision making and empowering teachers do not seem to be happened. However, it is argued that leadership outcomes for school principals were found, which enable them to transform their schools into better places for students to experience learning process. This paper aims to analyse the school principal's leadership styles, traits, skills, and key challenges in a non-government primary schools located in Riau province, Indonesia. The method used for data analysing is an interview with the principal using several questions which indicates leadership styles and practices. In addition, this paper finds that the principal does not have certain or specific leadership styles in leading the school, but uses more situational leadership styles. Indeed, the principal exhibited several styles: directive, people-oriented, taskoriented, and authoritarian. The principal's traits are identified as having integrity and self-efficacy while human, conceptual and alignment are perceived to be the skills in leading the school. At the last point, external factors have challenged the school to create customer satisfaction as this has been a concern of the principal in recent years.
\end{abstract}

Keywords: leadership, educational leadership, leadership styles, trait, skill.

\section{Introduction}

Leadership in education is not well-established or understood in Asia countries. As argued by Hallinger and Chen (2015), research into educational leadership and management in Asia is still in the beginning phase of development and the sources of knowledge in this field of study are unequally and insufficiently distributed across countries. More specifically, located in Southeast Asia, Indonesia is still lacking research into educational leadership (Raihani, 2008). However, OECD/ADB (2015) argues that the practice of educational leadership in Indonesia is not only seen from the perspective of research but also through educational reformation process, via decentralisation system which has been applied since 1999. Decentralisation in education is another form of educational leadership practice which includes the process of handing power over from central to regional educational authorities or institutions and is aimed at improving the quality of local educational sector (McGinn and Street, 1986). As Pidarta (2016) highlights, the practice of this system requires numerous qualified local leadership professionals but Indonesia has limited amount of human resources, particularly school leaders or principals who could enable schools to become more successful either in student attainment or teachers' competence in teaching and learning. Moreover, studies of the school principals' role in upgrading entire school components indicates the role is considered mostly autocratic where good practices such as shared decision making and empowering teachers do not seem to be happening (Bjork, 2005; Jones and Hagul, 2001; Sofo et al., 2012). However, another study found leadership outcomes for school principals which enable to transform their schools into better schools for students to experience learning process (Raihani, 2008). This paper aims to analyse school principal's leadership style in one of Indonesia's primary schools, taking into account the 
conceptualisation of leadership, leadership traits and skills, leadership styles and the key challenges during the principalship. As such, the following sections will further explore a description of the school context, theoretical background, data analysis and discussion, and provide a conclusion.

\section{Description of the school context}

The school in question is a private primary school which was established in 2006. Located in Riau Province, Indonesia, it is considered a small-scale school, where every grade is comprised of two different classes, for example, Primary 1A and 1B, with total number of students in each class ranging from 15 to 20 students. Recently, the school adopted Indonesia and Singapore curriculum and is known as a National Plus School, and the concept of such a school is to provide additional subjects taught in English and Mandarin such as English, Science, Mathematics and Chinese Language (Mandarin). Interestingly, this school accepts students with special needs condition such as ASD and ADHD and provides a teaching assistant or shadow teacher to support and guide these students during their life in the school.

\section{Theoretical Background}

\subsection{Conceptualisation of Leadership}

There are various concepts of leadership which the scholars in this field of study propose. Leadership is more about the process of challenging the status quo and constructing the rules of policy (Bush, 2011), as it is the process of transforming an organisation and being a role model who motivates staffs to achieve their goals. This entails using their initiative and taking risk (Cuban in Bush, 2011). Put simply, Hoy and Miskel (2013) provide a definition of leadership as the social practice in which an individual or a group influences behaviour toward a common goal. Either, it is supported by Northouse (2013) that basis of leadership is more general as it is the influence of an individual or group of people in achieving the common, shared goal. However, according to Sulistiani et al (2016) leadership is the ability of an individual not only to influence, but also to empower and lead others by stressing that staff are aware of no coercive values embedded. Together with this, leadership in brief is defined as the social influence of an individual or group of people where the element of coercion is not included within the belief of team members.

This paper finds an overlap in the conception of leadership and management in education in the literature (Bush, 2008). According Sapre in Bush (2011) management aspects due to its focus on efficiency and effective use of resources in achieving the goals of organisation. In contrast, Cuthbert (1984) describes management as obtaining people's in order to accomplish the goals of the organisation. From these definitions, it is argued that there is a core concept in which management allows people to experience the process of maintaining the effectiveness of the system and the agreed policy (Bolam in Bush, 2011). Along with this, it can be deduced that management is more generally focused on maintaining a process which involved people effectively accomplishing goals, while leadership is intended not only to influence others in achieving the goal, but also to frame new actions and execute them.

\subsection{Leadership Traits and Skills}

Within this section, several points will be discussed in relation to leadership traits and skills. In essence, the trait approach can be understood as the examination of what makes a certain individual become a great leader (Northouse, 2013). Northouse (2013) suggests the difference concept of leadership traits and skills where five main leadership traits are found - Intelligence, self-confidence, determination, integrity, and sociability - and three skill approaches are identified: technical, human, and conceptual.

Indeed, Hoy and Miskel (2013) suggest that the traits and skills approach is an emerging approach in relation to effective leadership in education. The approach consists of personality (self-confidence, stress tolerance, emotional maturity, integrity, extroversion), motivation (task and interpersonal needs, power needs, achievement orientation, high expectation, self-efficacy), and skills (technical, interpersonal, conceptual). Furthermore, Hoy and Miskel (2013) note that personality is simply a fixed character trait to act properly in certain way while 
motivation has been understood as the key factors in determining what leaders should do, and skill is the proxy element in completing the task.

Additionally, cultural characteristics of leadership in Southern Asia includes Indonesia exhibited high values on family loyalty and deep concern for their communities and effective leadership is shown as collaborative, inspirational, sensitive to people's needs, and concerned with status and face saving (Northouse, 2013).

\subsection{Leadership Styles}

Hoyle (2006) explained that leadership style comprises of a leader's general identity, disposition, and communication methods in guiding others toward achieving hierarchical or individual objectives. In the literature on educational leadership, several leadership styles are found in line with theories of Fiedler's Contingency model of leadership. Hoy and Miskel (2013) highlight that this theory shows leadership styles are determined by the motivational arrangement of leaders, that is, the hidden needs structure that spurs action in different interpersonal circumstances. As a result, Fiedler's contingency theory suggests two major leadership styles: task-motivated, where leaders tend to focus with the task and the outcomes of the work and relationshipmotivated, where leaders put high priority on building good communication with others and making the connection (Ibid., 2013). However, this theory is limited to the capacities which enable leaders to act in certain situations (Northouse, 2013). Alternatively, Hoyle (2006) suggests broader concepts of leadership styles: authoritarian, participative, transactional, and transformational. In addition, these styles are commonly found in educational research in relation to school principals' leadership styles research (Ibid, 2006).

\subsection{The Key Challenges in Leading the School}

In some research findings on principals' leadership challenges, principals in certain situation are indicated to be the victims of external constraints, such as parents' demands regarding their child's grades and greater concerns about their children to some extents (Hult et al, 2016). This is due to several factors including higher school fees, special educational needs concerns (Autism Spectrum Disorder (ASD), Attention Deficit Hyperactivity Disorder (ADHD) and disabled students (ibid., 2016). Indeed, another paper found that intersectionality is another issue perceived as a challenge for school principals, which focuses particularly on age and gender (Peters, 2012) given that a female principal participated in this interview. Nevertheless, this issue is not discussed in this essay as another finding from a study on an Indonesia school principal stated that they have less expertise and less experience to overcoming problems and handling challenges, and even to gain opportunities in educational autonomy (Bjork, 2005). Given that, de Gues cited in Haris (2003) emphasises that in facing challenges, leaders should nurture their capability of learning to change starting with themselves, then people surrounding them and then the organisation.

\section{Analysis and Discussion}

To obtain the data, the author used interview session via Skype with the school principal. Skype was chosen because it allowed the author to communicate easily across the difference countries and time zone. The duration of interview was 18 minutes and 39 seconds, conducted on 17th October 2016. However, additional interview session was conducted on 14th December to gain more additional information.

\subsection{The Background Information of Principal}

This paper considers as its participant a female principal who is 29 years old. This was done because she was the principal that the writer has experience in working with. It is noticeable that she has been working for 7 years and graduated from an English education faculty as the answer she provided below regarding the biographical background of the principal.

I was born in 1987, on 14th July. . . I got my bachelor degree in English study programme in teachers' training and education faculty. . . I have been working in this school since 2009 - Principal. 


\subsection{Principal's Leadership Conceptualization}

During the interview session, the principal described the concept of leadership as follow:

To be leader I have to be ready to help people around me to discover their own potential for themselves Principal

Essentially, social values embedded in conceptualizing leadership shown by helping people in order to actualize their potential as Hoy and Miskel (2013) explain that leadership as the social practice in which an individual or a group influences behaviour toward a common goal. However, the principal gives additional information as follows:

For me leadership is giving role model, team player, decision maker, risk taker, dreamer, goal setter, great planner, and most of all, a leader is a coach and facilitator of the team members - Principal

This finding suggests the broaden concept of leadership as it confirms the view from Cuban in Bush (2011) that is undertaking the process of transforming an organisation and being role model of leaders in motivating staffs to achieve goals, which entails using initiative and taking risk.

However, to some extent she states 'giving role model', which indicates her integrity in leadership trait. Hoy and Miskel (2013 p. 431) point out that integrity is the behaviour of leaders that is consistent with their stated values. Giving role model suggests the consistency of principals towards the value that she states which enable staffs to emulate.

\subsection{Principal's leadership Traits and Skills.}

Regarding to leadership traits and skills, the principal exhibits some performances. Given that, the following response is perceived to be the reason of the principal's appointment to be a school leader.

Then maybe at that time, the school manager and research and development division observed my class for several times and found that the result of my observation was achieved in all aspects. So, in the beginning of 2015 I was appointed to be the principal - Principal

The response shows that the principal has human skill as Northouse (2013) emphasizes that it is the knowledge about and ability to work with people since teaching involves working not only with individual, but also with groups of people (students). Along with this, seeing that the previous position of the principal was a classroom teacher and her teaching skill therefore was observed by school manager and a division, called research and development division for several times. By the time, the result of her observation was considered good where the expected aspects were all achieved. It is also supported by her quotation that her teaching experience has shaped her to be a principal:

I think teaching experience that I have now has shaped me to be a leader right now - Principal

However, another finding of leadership skill regarding the way the principal communicates with the staff.

Before going to the point, I want to assure that I want to tell the background first rather than straight to the topic... I also compose things over what I want to say first - Principal

The principal might consider conceptual skill in communicating with the staff which includes the capacity to shape and work with ideas (Hoy and Miskel, 2013). Also, conceptual skill is central to creating a vision and strategic plan for an organisation or institution (Northouse, 2013). Therefore, the principal provides the whole picture at the beginning before she delivers what needs to be spoken with the staffs.

Furthermore, alignment skill in leadership which is aimed at increasing engagement has been understood as the way leader engages staffs in order to feel aligned with their organisation's purpose, values and vision (Ayers, 2015). Taking into account, the principal shows her alignment skill in leading the school either as she mentioned:

I make sure everybody has the same knowledge and vision about the school, so that they are going to the right direction and no one is misleading - Principal 
On the other hand, this paper finds self-efficacy as one of the values in motivational traits. Hoy and Miskel (2013) in Bendura's self-efficacy theory explain that this is a value where leaders believe that they have the capacity to reach their target of success. Self-efficacy can be defined as the belief in one's ability to organize and carry out a course of action which is related to performance (Ibid., 2013). Therefore, the following statement shows the principal's self-efficacy in leading the school.

I don't really concern with people assumption... if it is good, I take it as compliment, however, if it is negative, I will do and improve my work to be better and prove them that they are wrong - Principal

In regards to people assumption, she tends to believe that anything negative issues on her behaviour can be proven wrong and focusing on how she could perform better by always learning and improving her work in order to be better. However, to some respect, it is identified that the principal tends to perform good or face saving in any condition as it is stated that one of the characteristics in effective leadership in Southern Asia is face saving (Northouse, 2013).

\subsection{Principal's Leadership Styles}

Seemingly, the principal tends to be situational as shown below:

I believe that a leader cannot always stay in one leadership style because leadership style should be situational - Principal

Cited in Northouse (2013) that situational leadership focuses on leadership in situation and is composed by directive and supportive behaviours. From the statement, it is clearly stated that she adopts situational leadership by stating she cannot focus only with one style instead of styles which based on situation. However, she gives additional points regarding to leadership style.

I will tell and show to my subordinates about how the things should be handled, how to do one thing, how to do another thing, and how to do everything - Principal

The response above indicates that she is a directive leader, as it is noted in Northouse (2013) that directive leader helps group members to accomplish goals by giving directions, establishing goals and methods of evaluation, setting time lines, defining roles and showing how the goals are to be achieved. However, since she adopts situational leadership, it is noticeable that the principal is identified as people-oriented as well which can be seen from her response below:

I also like to talk to subordinate in person, somehow, we do SWOT analysis, and then I asked them like how to set their own goal, so that they can check their own weaknesses and strengths - Principal

In Hoy and Miskel (2013) people-oriented leadership is indicated by helping others to feel comfortable, showing social and emotional support, asking for input, praising, sharing information about oneself and listening. Given that, talking personally with staff is identified as showing social and emotional support since this is done to find out the staff's strengths and weaknesses in completing the task. However, it seems that the leadership also tends to be task-oriented as she indicates that although she is still concerning in making good relationship with the staffs, she still remembers the goal that need to be achieved by individual as she emphasizes 'to set their own goal'.

Additionally, there is a certain condition that allows her to be an authoritarian as follows:

There is also some time I will be an authoritarian in leadership style... But if we are in a quite bad situation .I use authoritarian style so that the things can be handled quickly - Principal

To accomplish the task quickly, precisely in bad situation, the principal alternatively shifts her style into authoritarian. Hoyle (2006) suggests that authoritarian leadership is categorized as the style which enable leader to force the work done by staffs and display little emotion towards the staffs. This style basically adopts the concept of control which is the primary management strategy by the leader and to some extent, authoritarian leaders can be viewed as successful in certain task situation and condition (Ibid.,2006). 


\subsection{Principal's Challenges in Leading the School}

Private primary school that this paper focuses apparently show some findings in dealing with challenges which is identified from external factors.

The very big challenging is coming from the customer, our students' parents... particularly in any incidents that happen to their children.

In solving problems, we usually call and meet up with parents to talk and give solution. I will embrace it and react with it with intelligent effort and solution... the problem is not the obstacles or the challenges, but it is on how I react to them - Principal

Since the school is categorized as a private school, pressure from parents is perceived to be at the centre of the principal's challenges, which confirms the findings of Hult et al., (2016) that the principal is the victim of external constraints. It is easy to see from this fact that parents have less trust and confidence to the school because Hult et al., (2016) claims, the money that parents spend on their children informs the higher demands that they impose on the school. However, meeting up and talking with parents to provide solutions are the inputs that the principal offers to face and overcome these challenges. Also, she learns from challenges and problems in how she reacts to them and provides smart solution.

On the other hand, the impact of leadership is not clearly stated by the principal, it might be indicated by her reluctance to expose the impact of her leadership period.

I haven't seen a huge impact of my leadership in this organisation, until now I never satisfied with what I have done - Principal

This answer suggests that either she is aware of the impact that she makes on to the organisation or the converse. The tendency is therefore to see from her perspective only, not from the staffs or even the students, which limits this finding.

\section{Conclusion}

This paper has shown various findings regarding the principal's leadership style in an Indonesia primary school context. It is found that leadership as the process of influencing people, being a role model and becoming a risk taker. The principal is identified as having integrity and self-efficacy traits. Interestingly, her teaching experience has apparently brought her into a school leader position and conceptual skill which eventually put her at ease in communicating with the staffs. Alignment skill surprisingly allows her to engage staffs to align to the purpose, values, and vision of school. Furthermore, it is evinced that the principal has concept of situational leadership in leading the school although directive, people-oriented, task-oriented and authoritarian are the main styles identified. This tendency implies that certain factors and conditions may initiate her shifting in styles during the principalship. In addition, her main challenge is seemingly rooted in an external factor - the rising issue of unsatisfied customers - which impose more demands on the school. Finally, the impact of leadership practice on this school has prompted the author to make recommendations for future analyses or research at this point was no identified due to the principal's reluctance.

Therefore, what can be learned from this principal is her consistency in sharpening her skill in teaching. This is an additional point from a leader who has qualified teaching skills and experience which led her to the position of leader. However, an area of improvement which became a concern is handling complaints from parents. It seems that this is very serious problem happening within the school. No other issue, such as human resources, budget or curriculum design was mentioned. Presumably, there is a need for improvement in the way the principal leads the school in terms of the satisfactory of external demands, as the school requires a greater budget for the students annually.

\section{References}

[1] Ayers, K. (2015). Positive Inspirational Leadership Stories, Available at: http://www.agiftofinspiration.com.au/stories/leadership/Five.shtml (Accessed: 6th January 2017).

[2] Bush, T. (2008). From management to leadership: semantic or meaningful change? Educational Management, Administration and Leadership, 36(2), 271- 288

https://doi.org/10.1177/1741143207087777. 
[3] Bush, T. (2011). Theories of educational leadership and management, 4th edn, Sage, London; Los Angeles.

[4] Bjork, C. (2005). Indonesian education: Teachers, schools and central bureaucracy. New York: Routledge.

[5] Cuthbert, R. (1984). "The management process", E324 Management in Post Compulsory Education, Block, vol. 3.

[6] Hallinger, P. \& Chen, J. (2015). "Review of research on educational leadership and management in Asia A comparative analysis of research topics and methods, 1995-2012", Educational Management Administration \& Leadership, vol. 43, no. 1, pp. 5-27. https://doi.org/10.1177/1741143214535744

[7] Harris, A. (2003). Effective leadership for school improvement, London: RoutledgeFalmer.

[8] Hoy, W.K., \& Miskel, C.G. (2013). Educational administration: theory, research, and practice, 9th edn., New York: McGraw-Hill.

[9] Hoyle, John R (2006). "Leadership Styles." Encyclopedia of Educational Leadership and Administration. Ed. Thousand Oaks, CA: SAGE, 595-98. SAGE Reference Online. Web. 30 Jan. 2012. https://doi.org/10.4135/9781412939584.n334

[10] Hult, A., Lundström, U. \& Edström, C. (2016). "Balancing managerial and professional demands: school principals as evaluation brokers", Education Inquiry, vol. 7, no. 3.

[11] Jones, G.W. \& Hagul, P. (2001). "Schooling in Indonesia: crisis-related and longer-term issues", Bulletin of Indonesian Economic Studies, vol. 37, no. 2, pp. 207-231.

https://doi.org/10.1080/00074910152390892

[12] Northouse, P.G., (2013). Leadership: theory and practice. 6th edn., Thousand Oaks: Sage.

[13] OECD/ADB (2015). "Teaching and educational leadership in Indonesia", in Education in Indonesia: Rising to the Challenge, Paris: OECD Publishing.

[14] Pidarta, M. (2016). "Desentralisasi Pendidikan di Tingkat Kabupaten", Jurnal Ilmu Pendidikan, vol. 8, no. 1.

[15] Raihani (2008). 'An Indonesian model of successful school leadership', Journal of Educational Administration, 46(4), pp. 481-496. doi: 10.1108/09578230810882018. https://doi.org/10.1108/09578230810882018

[16] Sulistiyani, D., Minarsih, M.M. \& Hasiholan, L.B. (2016). "Pengaruh Gaya Kepemimpinan Transformational Kepala Sekolah, Iklim Organisasi dan Gaji Honorer Terhadap Motivasi Kerja Sub Bagian Tata Usaha (Studi Kasus Pada Sub Rayon 03 SMP 11, SMP 12, SMP 17, SMP 24, SMP 26 SMP 27 Kota Semarang)", Journal of Management, vol. 2, no. 2.

[17] Sofo, F., Fitzgerald, R., \& Jawas, U. (2012). Instructional leadership in Indonesian school reform: overcoming the problems to move forward. School Leadership \& Management, 32(5), 503-522.

https://doi.org/10.1080/13632434.2012.723616 